\title{
PEMEROLEHAN KOSAKATA SISWA PAUD AL-ISTIQLAL DENGAN STRATEGI PENGGUNAAN BENTUK NONVERBAL
}

\author{
Dzarna \\ Universitas Muhammadiyah Jember \\ dzarna@unmuhjember.ac.id \\ Diterima: 18 Januari 2019 \\ Publikasi: 27 Februari 2019 \\ DOI: http://dx.doi.org/10.32528/bb.v4i1.1864
}

\begin{abstract}
ABSTRAK
Pemerolehan bahasa tentunya dimulai sejak dini, dapat berbahasa ada prosedur yang harus dilakukan. Prosedur yang pertama harus belajar kosa kata. kosa kata yang dimiliki anak Paud Al Istiqlal terbilang masih sedikit, guru kelasnya yang mengatakan. Banyak atau sedikitnya kosakata anak dipengaruhi oleh faktor keluarga dan lingkungannya. Salah satu cara agar anak mendapatkan kosa kata dengan cara memberikan gambar dan mengenalkan nama gambar. Tujuannya adalah mengetahui pemerolehan kosakata siswa dengan penggunaan bentuk nonverbal (gambar). Jenis penelitian menggunakan pendekatan kualitatif. Sumber data adalah hasil gambar yang telah dijawab oleh siswa yang berjumlah 12 orang. Teknik pengumpulan data dengan penugasan. Teknik penganalisisan data dengan pereduksian data, paparan data, dan penarikan kesimpulan. Pengecekan keabsahan data dengan ketekunan pengamat. Berdasarkan hasil penelitian yaitu dari tema bandara, bulan, jalan, kapal bajak laut, pertanian dan laut siswa dapat menjawab atau memperoleh kosa kata yang sering mereka jumpai di lingkungan sekitar. Mereka dapat menyebutkan nama gambar dikarenakan mereka pernah tahu gambar itu sekilas entah di buku, di jalan, atau dimanapun. Berbeda dengan anak yang tidak dapat menjawab, mereka mengatakan tidak tahu gambar tersebut dan tidak pernah melihat sebelumnya sehingga tidak dapat menyebutkan. Jadi, pemerolehan bahasa setiap anak berbeda-beda, hal ini dikarenakan bedanya status sosial, keluarga, dan lingkungan.
\end{abstract}

Kata Kunci: Pemerolehan Kosakata, Penggunaan Gambar.

\begin{abstract}
Language acquisition certainly starts early, can speak there is a procedure that must be done. The first procedure must be vocabulary learning. The children vocabulary of Paud Al Istiqlal's is still small, the class teacher said. Many or at least the vocabulary of children is influenced by family and environmental factors. One way to get children to get vocabulary is by giving pictures and introducing names of images. The aim is to find out the acquisition of student vocabulary with the use of nonverbal forms (images). This type of research uses a qualitative approach. Data sources are the results of images that have been answered by students totaling 12 people. Data collection techniques with assignments. Technique of analyzing data by reducing data, data exposure, and drawing conclusions. Check the validity of the data with the perseverance of the observer. Based on the results of research, namely from the theme of the airport, moon, roads, pirate ships, agriculture and the sea students can answer or obtain vocabulary that they often encounter in the surrounding environment. They can mention the name of the picture because they once knew the picture at a glance whether in a book, on the road, or anywhere. In contrast to children who cannot answer, they say they do not know the picture and have never seen it before so that they cannot mention it. So, the acquisition of each child's language is different, this is due to the difference in social, family, and environmental status
\end{abstract}

Keywords: Vocabulary Acquisition, Use of Images. 


\section{PENDAHULUAN}

Bahasa merupakan alat yang digunakan oleh manusia untuk berkomunikasi dengan lingkungannya. Menurut Kridalaksana (2008:25) bahasa adalah sistem lambang bunyi yang dipergunakan oleh para anggota suatu masyarakat untuk bekerja sama, berinteraksi, dan mengidentifikasi diri. Sejak lahir, manusia sebenarnya telah memiliki bahasa untuk berkomunikasi dengan orang terdekatnya. Contoh, seorang bayi akan menangis jika ia merasa lapar, ia akan menangis juga ketika ia merasa tidak nyaman karena telah buang air.

Seiring berjalannya waktu, seorang bayi akan tumbuh menjadi seorang anak. Seorang anak menggunakan bahasa pertamanya untuk menyampaikan keinginannya kepada orang terdekat yaitu orang tuanya. Dengan demikian peran orang tua sangat penting dalam perkembangan bahasa seorang anak. Anak harus terus menerus diajarkan cara berbahasa dengan baik sesuai dengan tingkat usianya. Anak pun akan menyimak serta menirukan apa yang orang tuanya ucapkan.

Proses yang sistematis dalam menguasai suatu bahasa yang dialami oleh anak dinamakan proses pemerolehan bahasa. Pemerolehan bahasa didefinisikan sebagai proses penguasaan bahasa yang dilakukan oleh anak secara natural pada waktu dia belajar bahasa ibunya (Dardjowidjojo, 2005:225). Bahasa pertama atau bahasa ibu cenderung kepada bahasa tempat anak tinggal dan dibesarkan. Pemerolehan bahasa anak dimulai sejak 0-5 tahun. Semakin bertambahnya usia anak semakin bertambahnya pula kemampuan berbahasa anak. Sedangkan menurut Chaer (2009: 167) menyatakan bahwa pemerolehan bahasa atau akuisisi bahasa adalah proses yang berlangsung di dalam otak seseorang kanak-kanak ketika dia memperoleh bahasa pertamanya atau bahasa ibunya. Proses ini membutuhkan waktu dimana anak akan mengenal kosakata kemudian merangkai kosakata menjadi kalimat sehingga terbentuklah sebuah bahasa yang memiliki makna dan dimengerti pendengarnya.

Kosakata adalah kekayaan kata yang dimiliki oleh suatu bahasa (Soejito: 2011:3) Banyaknya bahasa (kosakata) anak dipengaruhi oleh beberapa faktor, diantaranya faktor orang tua. Orang tua seharusnya sejak hamil harus memberikan stimulus terhadap anak. Misal sejak dikandungan, anak harus selalu diajak berbicara. Meski berada di kandungan, anak akan merespon bahasa ibunya. Missal, dia kan menendang-nendang saat ibunya mengajaknya berbicara. Begitu juga saat lahir, ibu harus selalu mengajak anak berbicara. Apalagi pada saat-saat usia anak kurang lebih 2 tahun. Usia dua tahun, anak sudah banyak bertanya nama benda ini dan itu. Disinilah peran ibu yang sangat penting untuk mengenalkan nama-nama benda di sekitar kepada anak. Dengan demikian, akan banyak kosakata yang diperoleh anak. 
Berbeda dengan anak yang tidak pernah mendapat stimulus sejak kandungan, apalagi saat ia lahir orang tua tidak dekat dengan anak. Maka, bahasa/kosakata si anak ini akan berbeda dengan kosakata yang telah diperoleh anak yang dekat dengan ibunya. Dari wawancara peneliti dengan guru Paud Al-Istiqlal, bahwa di Paud ini siswanya dari berbagai macam keluarga, dalam artian ada anak yang tinggal bersama kedua orang tuanya, tinggal bersama kakek neneknya, tinggal bersama neneknya saja, bahkan ada yang tinggal bersama orang tua kandungnya (ayah kandung) dan bersama ibu tirinya. Dengan demikian, jelas bahasa/kosakata yang diperoleh anak akan beragam.

Tujuan dari penelitian ini yaitu mengetahui pemerolehan bahasa (kosakata) siswa Paud Al Istiqlal dengan menggunakan strategi gambar. Penggunaan gambar merupakan strategi penggunaan bentuk nonverbal yang digunakan penutur anak, untuk mengatasi kendala komunikasi yang dihadapinya (Werdiningsih, 2011:57). Peneliti akan menunjukkan nama gambar kepada siswa, kemudian siswa menyebutkan nama gambar tersebut. Dengan demikian, akan ditemukan sejauh mana pemerolehan bahasa (kosakata) siswa Paud Al Istiqlal. Manfaat penelitian ini, dimana anak akan mengenal nama gambar yang ditunjukkan peneliti. Dengan demikian bertambahlah kosakata pada anak Paud AlIstiqlal.
Penelitian bahasa anak banyak dilakukan peneliti lainnya, seperti penelitian pemerolehan bahasa anak yang dilakukan oleh Candrasari(2014) dari Universitas Muhammadiyah Surakarta jurusan PBSI, FKIP. Penelitiannya terkait dengan pemerolehan bahasa anak usia 3-4 tahun di Desa Gembong Kecamatan Belik Kabupaten Pemalang. Hasilnya yaitu pemerolehan bahasa anak usia 3-4 tahun menyangkut bentuk kalimat dan fungsi bahasa yang sudah

dikuasai (http://eprints.ums.ac.id/id/eprint/29874).

Sedangkan pada penelitian ini menyangkut tentang pemerolehan kosakata dengan menggunakan gambar, dimana peneliti menunjukkan dan menyebutkan nama gambar pada siswa, dan siswa akan memperoleh kosakata baru dengan melihat gambar yang ditunjukkan.

\section{METODE PENELITIAN}

Metode yang digunakan pada penelitian ini menggunakan metode kualitatif. Melalui metode kualitatif ini akan dideskripsikan pemerolehan kosakata siswa Paud AlIstiqlal. Moleong (2010:6) menyatakan bahwa penelitian kualitatif adalah penelitian yang bermaksud untuk memahami fenomena tentang apa yang dialami oleh subjek penelitian misalnya perilaku, persepsi, motivasi, tindakan, secara holistik dan dengan cara deskripsi dalam bentuk kata-kata dan bahasa, pada suatu konteks khusus yang alamiah dan dengan memanfaatkan berbagai metode 
ilmiah. Pada penelitian ini, peneliti akan memahami fenomena yang dialami oleh siswa Paud Al-Istiqlal ketika memperoleh kosakata yang belum mereka dapatkan dengan menggunakan media gambar.

Sumber data pada penelitian ini adalah hasil gambar yang telah dijawab oleh siswa Paud Al-Istiqlal yang beralamat di Jalan Kapten Piere Tendean No.49 Kelurahan Karangrejo Kecamatan Sumbersari Kabupaten Jember. Siswa AlIstiqlal ada dua kelas, kelas nol kecil dan nol besar. Peneliti memilih nol besar yang berjumlah 16 siswa baik laki-laki dan perempuan. Pengumpulan data pada penelitian ini menggunakan teknik tes (penugasan), yaitu peneliti memberikan gambar yang terdiri 6 tema dan masingmasing tema memiliki macam-macam gambar dan menjelaskan nama gambar tersebut kemudian peneliti memberikan gambar lagi/gambar yang sama dan siswa disuruh menyebutkan nama gambar tersebut. Siswa yang menjawab benar gambar tersebut, maka gambar akan diberitanda $v$. Tema yang peneliti pilih adalah tema yang ada di lingkungan sekitar agar memudahkan siswa ketika mengenal gambar. Tema-tema tersebut adalah tema bandara, bulan, jalan, kapal bajak laut, pertanian, dan laut.

Rancangan penelitian adalah rencana atau struktur penelitian yang disusun sedemikian rupa sehingga kita dapat memperoleh jawaban atas permasalahan-permasalahan penelitian
(Setyosari, 2010:148). Rancangan penelitian pada penelitian ini dilakukan dua hari, hari pertama peneliti mengenalkan gambar dan menjelaskan nama gambar tersebut, dengan demikian siswa akan mengingat apa nama gambar tersebut. Gambar yang peneliti tunjukkan terdapat tujuh tema. Tema (1) bandara, (2) bulan, (3) jalan, (4) kapal bajak laut, (5) pertanian, dan (6) laut.Hari kedua, peneliti menunjukkan masing-masing gambar kepada masingmasing siswa, dan siswa akan menyebutkan nama-nama gambar. Dengan demikian peneliti akan mengetahui sejauh mana siswa memperoleh bahasa (kosakata) dengan gambar. Setelah selesai, hasil atau tugas yang dilakukan siswa akan dianalisis oleh peneliti, tetapi sebelumnya akan dilakukan, (1) mengecek hasil siswa sesuai jumlah siswa, (2) memilah gambar yang telah dijawab dengan benar dan jawaban yang benar akan diberi tanda $v$, kemudian dimasukkan dalam tabel pengumpulan data untuk memudahkan peneliti saat mengolah data. Tabel pengumpulan data akan disajikan dipembahasan. (3) menganalisis sejauh manakah siswa Paud memperoleh kosakata dengan penggunaan gambar.

Teknik pengumpulan data dalam penelitian ini menggunakan metode simak. Metode penyediaan data ini diberi nama metode simak karena cara yang digunakan untuk memperoleh data dilakukan dengan menyimak penggunaan bahasa (Mahsun, 2011:92). Disaat peneliti mengumpulkan data, peneliti hanya menyimak jawaban 
siswa saat siswa menyebutkan nama-nama gambar yang peneliti tunjukkan. Peneliti tidak berkomunikasi dengan siswa hanya menyimak apa yang siswa jawab. Ketika proses pengumpulan data, peneliti menyediakan tabel pengumpulan data dan nama-nama siswa peneliti beri kode siswa. Misal S1 adalah siswa ke-1, S2 siswa ke-2, dan seterusnya hingga S12. Kode siswa berfungsi memudahkan peneliti ketika menganalisis data. Tabel pengumpulan data akan peneliti cantumkan pada hasil dan pembahasan.

Pada analisis data, yang pertama peneliti lakukan mengenalkan gambar pada siswa, kemudian siswa menyebutkan masing-masing gambar dan peneliti memberikan tanda $v$. Setelah data terkumpul, peneliti mengelompokkan gambar-gambar yang telah terjawab dan gambar yang tidak dijawab. Dengan cara ini, akan diketahui tentang pemerolehan bahasa (kosakata) siswa. Selanjutkan akan melakukan kesimpulan.

Pengecekan keabsahan adalah cara terbaik untuk menghilangkan perbedaanperbedaan konstruksi kenyataan yang ada dalam konteks suatu studi sewaktu mengumpulkan data tentang berbagai kejadian dan hubungan dari berbagai pandangan (Moleong, 2010:332). Ada tujuh teknik pengecekan keabsahan data, diantaranya (1) perpanjangan keikutsertaan, (2) ketekunan pengamatan, (3) triangulasi, (4) pengecekan sejawat, (5) kecukupan referensial, (6) kajian kasus negatif, dan (7) pengecekan anggota (Moleong, 2010:327).

Teknik yang dilakukan peneliti untuk pengecekan keabsahan data adalah ketekunan pengamatan, yaitu menemukan ciri-ciri dan unsur-unsur dalam situasi yang sangat relevan dengan persoalan yang sedang dicari kemudian memusatkan pada hal-hal tersebut secara rinci. Dengan melakukan ketekunan pengamatan, datadata yang ditemukan peneliti akan semakin benar bahwa data-data tersebut benarbenar sesuai dengan gambar yang diberikan peneliti.

\section{PEMBAHASAN}

Jumlah siswa keseluruhan di kelas nol besar adalah 16 orang, namun yang hadir hanya 12 orang, empat orang tidak hadir dikarenakan sakit dan ada kepentingan lain. Siswa siswi tersebut diantaranya Rangga (S1), Dina(S2), Cinta (S3), Gilang (S4), Aril (S5), Radit (S6), Puspa (S7), Fito (S8), Fero (S9), Erin (S10), Intan (S11), Firman (S12). Peneliti memberikan kode $S$ adalah siswa, dan 1-12 jumlah anak. jadi S1 adalah siswa ke-1, S2 adalah siswa ke-2, dst.Peneliti memberikan enam tema kepada masing-masing siswa. Berikut penjelasannya: 
Tema pertama dengan tema bandara

\begin{tabular}{|c|l|c|c|c|c|c|c|c|}
\hline No & Nama & \multicolumn{7}{|c|}{ Jenis gambar } \\
\hline & Siswa & $\mathbf{1}$ & $\mathbf{2}$ & $\mathbf{3}$ & $\mathbf{4}$ & $\mathbf{5}$ & $\mathbf{6}$ & $\mathbf{7}$ \\
\hline 1 & S1 & $\sqrt{ }$ & $\mathrm{V}$ & & & & & \\
\hline 2 & S2 & $\mathrm{V}$ & $\mathrm{V}$ & & $\mathrm{V}$ & & $\mathrm{V}$ & \\
\hline 3 & S3 & $\mathrm{V}$ & $\mathrm{V}$ & & $\mathrm{V}$ & & & \\
\hline 4 & S4 & $\mathrm{V}$ & $\mathrm{V}$ & & $\mathrm{V}$ & & $\mathrm{V}$ & \\
\hline 5 & S5 & $\mathrm{V}$ & $\mathrm{V}$ & & $\mathrm{V}$ & $\mathrm{V}$ & $\mathrm{V}$ & \\
\hline 6 & S6 & $\mathrm{V}$ & $\mathrm{V}$ & & & & $\mathrm{V}$ & \\
\hline 7 & S7 & $\mathrm{V}$ & $\mathrm{V}$ & $\mathrm{V}$ & & & & \\
\hline 8 & S8 & $\mathrm{V}$ & $\mathrm{V}$ & $\mathrm{V}$ & & & & \\
\hline 9 & S9 & $\mathrm{V}$ & $\mathrm{V}$ & $\mathrm{V}$ & & & & \\
\hline 10 & S10 & $\mathrm{V}$ & $\mathrm{V}$ & $\mathrm{V}$ & & & & \\
\hline 11 & S11 & & & & & & & \\
\hline 12 & S12 & $\mathrm{V}$ & $\mathrm{V}$ & & $\mathrm{V}$ & & & \\
\hline
\end{tabular}

Ket:tabel 1.gambar kapal udara, 2. gambar pilot, 3.gambar landasan, 4. gambar penumpang, 5.gambar pramugari, 6. gambarbagasi, 7. gambar garbarata

Tema pertama dengan tema bandara terdapat tujuh gambar, yaitu gambar kapal udara, pilot, landasan, penumpang, pramugari, bagasi, dan garbarata. Dari 12 siswa, terdapat 11 siswa yang dapat menjawab gambar kapal udara dan pilot, hanya kode siswa S11 yang tidak dapat menjawab. Hal ini dikarenakan kapal udara dan pilot sering mereka jumpai dibuku-buku sekolah mereka. Gambar landasan dapat dijawab oleh kode S7, S8, S9, dan S10, sedangkan yang lainnya tidak dapat menjawab. Mereka tidak dapat menjawab dikarenakan tidak pernah melihat gambar landasan udara. Begitu juga dengan gambar penumpang, yang dapat menjawab hanya kodeS2, S3, S4, dan S5, dan S12 mereka mengatakan dapat menjawab dikarenakan pernah melihat gambar tersebut dan yang lain tidak.

Berikutnya gambar pramugari, dari 12 siswa hanya satu yang dapat menjawab gambar tersebut yaitu kode S5. Hal ini dikarenakan kata pramugari susah diucapkan oleh mereka. Jika dipisah suku katanya menjadi,

\section{Pra-mu-ga-ri}

Suka kata "pra" terdapat huruf konsonan di depan dan berikutnya. Jadi ini yang menyebabkan gambar pramugari tidak mereka sebutkan kecuali kode S5. Selain itu mereka juga mengatakan bahwa tidak pernah melihat dan tidak tahu siapa itu pramugari, sehingga tidak dapat mereka sebutkan.

Lanjut kegambar berikutnya yaitu gambar bagasi, hanya empat siswa yang dapat menyebutkan, hal ini dikarenakan mereka tahu apa itu bagasi dan yang lain tidak. Terakhir adalah gambar garbarata. Dari pengucapannya saja susah, yaitu jika dipisah suku katanya menjadi gar-ba-ra-ta. 
Gambar tersebut semua siswa tidak dapat menyebutkan, hal ini dikarenakan mereka tidak tahu apa itu garbarata, dan mengucapankannyapun susah disebutkan oleh anak seusia dini. Sehingga dari 12 siswa tidak ada satupun yang dapat menyebutkan. Pada tema pertama ini terdapat satu siswa yaitu kode S11, dimana S11 tidak dapat menjawab semua gambar, entah dikarenakan gambar-gambar tersebut belum ia lihat atau la memang tidak dapat mengingat gambar yang peneliti tunjukkan

Dapat disimpulkan bahwa dari tema satu yang terdiri dari gambar kapal udara, pilot, landasan, penumpang, pramugari, bagasi, dan garbarata. Sebagian siswa dapat menyebutkan gambar yang pernah mereka lihat, dan siswa yang tidak dapat menyebutkan dikarenakan mereka tidak tahu, tidak pernah melihat dan susah mengucapankannya.

\section{Tema kedua dengan tema bulan}

\begin{tabular}{|c|l|l|l|l|l|l|l|l|}
\hline No & Nama & \multicolumn{6}{|c|}{ Jenis Gambar } \\
\cline { 5 - 9 } & Siswa & $\mathbf{1}$ & $\mathbf{2}$ & $\mathbf{3}$ & $\mathbf{4}$ & $\mathbf{5}$ & $\mathbf{6}$ & $\mathbf{7}$ \\
\hline 1 & $\mathrm{~S} 1$ & & & $\mathrm{~V}$ & & $\mathrm{~V}$ & & $\mathrm{~V}$ \\
\hline 2 & $\mathrm{~S} 2$ & & $\mathrm{~V}$ & $\mathrm{~V}$ & $\mathrm{~V}$ & $\mathrm{~V}$ & $\mathrm{~V}$ & $\mathrm{~V}$ \\
\hline 3 & $\mathrm{~S} 3$ & $\mathrm{~V}$ & $\mathrm{~V}$ & $\mathrm{~V}$ & $\mathrm{~V}$ & $\mathrm{~V}$ & & $\mathrm{~V}$ \\
\hline 4 & $\mathrm{~S} 4$ & & & $\mathrm{~V}$ & $\mathrm{~V}$ & $\mathrm{~V}$ & $\mathrm{~V}$ & $\mathrm{~V}$ \\
\hline 5 & $\mathrm{~S} 5$ & & $\mathrm{~V}$ & $\mathrm{~V}$ & $\mathrm{~V}$ & $\mathrm{~V}$ & & $\mathrm{~V}$ \\
\hline 6 & $\mathrm{~S} 6$ & & $\mathrm{~V}$ & $\mathrm{~V}$ & $\mathrm{~V}$ & $\mathrm{~V}$ & $\mathrm{~V}$ & $\mathrm{~V}$ \\
\hline 7 & $\mathrm{~S} 7$ & & $\mathrm{~V}$ & $\mathrm{~V}$ & $\mathrm{~V}$ & $\mathrm{~V}$ & $\mathrm{~V}$ & $\mathrm{~V}$ \\
\hline 8 & $\mathrm{~S} 8$ & & $\mathrm{~V}$ & $\mathrm{~V}$ & $\mathrm{~V}$ & $\mathrm{~V}$ & & $\mathrm{~V}$ \\
\hline 9 & $\mathrm{~S} 9$ & & & $\mathrm{~V}$ & $\mathrm{~V}$ & $\mathrm{~V}$ & $\mathrm{~V}$ & $\mathrm{~V}$ \\
\hline
\end{tabular}

\begin{tabular}{|l|l|l|l|l|l|l|l|l|}
\hline 10 & S10 & & & v & v & V & & v \\
\hline 11 & S11 & & & v & V & V & & v \\
\hline 12 & S12 & & v & v & v & V & & v \\
\hline
\end{tabular}

Ket: tabel 1. gambarantariksawan, 2.gambar bumi, 3. gambarbendera, 4. gambar Jejak kaki, 6. gambarpesawat, 7. gambarbintang.

Tema kedua dengan tema bulan terdapat tujuh gambar diantaranya gambar antariksawan, bumi, bendera, jejak kaki, batu, pesawat, dan bintang. Gambar bendera, batu, dan bintang dapat dijawab oleh semua siswa, dikarenakan ketiga gambar tersebut sering mereka dengar. Begitu juga dengan jejak kaki, gambar tersebut dapat dijawab oleh 11 siswa, dikarenakan jejak kaki juga sering mereka dengar. Gambar antariksawan dari 12 siswa hanya kode S3 yang dapat menjawab gambar tersebut. Jika dilihat dari gambarnya, kemungkinan gambar antariksawan tidak pernah mereka lihat sebelumnya, dan dari pengucapannya jugasusah disebutkan. Jika dipisah suku katanya menjadi, an-ta-rik-sa-wan, dimana ada huruf vokal "a" dan " $\mathrm{n}$ " sehingga siswa ketika mengawali mengucapnya susah yaitu berbunyi "an" dan akhirannya pun "wan" dimana siswa susah untuk mengucapkannya. Sehingga ya telah peneliti kenalkan sebelumnya bahwa itu adalah gambar antariksawan, tetapi siswa tidak dapat memperoleh bahasa atau kosa kata tersebut dikarenakan susah pengucapannya. 
Berikutnya gambar bumi, dimana terdapat 12 siswa yang mampu menyebutkan hanya 7 siswa dan gambar pesawat hanya 5 siswa yang dapat menjawab. Hal ini dikarenakan memang bahasa yang dimiliki seorang anak bervariasi, kosa kata yang banyak dimiliki dikarenakan adanya faktor keluarga dan lingkungannya. Bumi dan pesawat sebenarnya sering dijumpai dimana-nama, tetapi siswa yang tidak dapat menyebutkan dikarenakan la memang tidak tahu gambar tersebut.

Tema ketiga dengan tema jalan

\begin{tabular}{|c|c|c|c|c|c|c|c|c|}
\hline \multirow[t]{2}{*}{ No } & \multirow{2}{*}{$\begin{array}{l}\text { Nama } \\
\text { Siswa }\end{array}$} & \multicolumn{7}{|c|}{ Jenis Gambar } \\
\hline & & 1 & 2 & 3 & 4 & 5 & 6 & 7 \\
\hline 1 & S1 & $\mathrm{V}$ & $\sqrt{ }$ & $\sqrt{ }$ & $\sqrt{ }$ & & & \\
\hline 2 & S2 & V & $\sqrt{ }$ & V & $\mathrm{V}$ & & $\mathrm{V}$ & \\
\hline 3 & S3 & $\mathrm{V}$ & $\sqrt{ }$ & $\sqrt{ }$ & $\mathrm{V}$ & & $\mathrm{V}$ & \\
\hline 4 & S4 & $\sqrt{ }$ & $\sqrt{ }$ & $\sqrt{ }$ & V & & & \\
\hline 5 & S5 & V & v & V & V & & V & \\
\hline 6 & S6 & V & V & $\sqrt{ }$ & $\mathrm{V}$ & & $\mathrm{V}$ & \\
\hline 7 & S7 & $\mathrm{V}$ & $\sqrt{ }$ & $\sqrt{ }$ & $\mathrm{V}$ & & $\mathrm{V}$ & \\
\hline 8 & S8 & $\mathrm{V}$ & & V & & & $\mathrm{V}$ & \\
\hline 9 & S9 & $\mathrm{v}$ & $\sqrt{ }$ & $\sqrt{ }$ & $\mathrm{V}$ & & $\mathrm{V}$ & \\
\hline 10 & S10 & $\mathrm{V}$ & $\sqrt{ }$ & $\sqrt{ }$ & $\mathrm{V}$ & & $\mathrm{V}$ & \\
\hline 11 & S11 & $\mathrm{V}$ & $\sqrt{ }$ & $\sqrt{ }$ & $\mathrm{V}$ & & $\mathrm{V}$ & \\
\hline 12 & S12 & V & $\sqrt{ }$ & $\sqrt{ }$ & $\mathrm{V}$ & & $\mathrm{V}$ & \\
\hline
\end{tabular}

Ket: tabel 1.gambar sepeda motor, 2.gambar bis, 3.gambar anjing

4. gambarpolisi, 5.gambar rambu lalu lintas, 6.gambar lampu merah, 7. Gambar zebracros.
Tema ketiga dengan tema jalan terdapat 7 gambar diantaranya gambar sepeda motor, bus, anjing, polisi, rambu lalu lintas, lampu merah, dan zebracross. Gambar sepeda motor, bus, anjing, polisi, dan lampu merah rata-rata siswa dapat menyebutkan, hanya kode S8 yang tidak dapat menyebutkan bus dan polisi, dan kode S1 dan S4 tidak dapat menyebutkan lampu merah.

Sebenarnya dalam kehidupan sehari-hari sering dijumpai gambar tersebut dan gambar tersebut juga bersifat umum, namun masih ada beberapa siswa yang tidak dapat menyebutkan gambar tersebut dikarenakan memang bahasa setiap anak berbeda. Gambar rambu lalu lintas dan zebracrosstidak dapat dijawab oleh semua siswa. Siswa mengatakan tidak tahu gambar tersebut, walaupun saat peneliti mengenalkan gambar tersebut adalah gambar rambu lalu lintas dan zebracross namun siswa tidak dapat mengingat serta menjawabnya.

Rambu lalu lintas adalah tanda untuk pengendara motor dan mobil. Terdapat tiga warna yaitu merah,kuning, dan hijau. Dimana merah menunjukkan tanda pengendara harus berhenti, kuning harus berhati-hati dan hijau pengendara harus berjalan. Kemungkinan siswa tidak dikenalkan oleh orang tuanya kalau namanya adalah rambu lalu lintas, sehingga siswa tidak dapat mengingat dan menjawab gambar yang peneliti berikan. Begitu juga 
dengan zebracross. Zebracross adalah garisgaris putih yang ada di jalan dan fungsinya untuk pejalan kaki ketika hendak menyeberang. Siswa mengatakan tidak tahu zebracross, dan kata zebracross mengucapannya juga susah untuk diucapkan, jika dipisah kosakatanya menjadi zeb-ra-cross. Akhirannya ada suku kata "cross", dimana ada huruf konsonan " $c$ " dan konsonan " $r$ " yang bersamaan sehingga susah mengucapannya.

Pengucapan atau bunyi dalam bahasa disebut fonologi, seperti pada penelitian sebelumnya yaitu penelitian milik Yanti (2016)yang berjudul Pemerolehan Bahasa Anak:Kajian Aspek Fonologi Pada Anak Usia 2-2,5 Tahun yang menyimpulkan bahwa bunyi lateral (I) sudah dikuasai anak, sedangkan bunyi getar $(r)$ belum. Bunyi likuid yang berupa lateral (I) muncul terlebih dahulu setelah bunyi hamat ringan, sedangkan bunyi ( $r$ ) belum muncul karena diduga lebih sulit mengucapankannya. Jadi jelas bahwa kata zeracrosssusah menyucapankannya karena terdapat konsonan-konsonan yang bersebelahan yaitu "cr", begitu juga dengan kata pramugari pada tema pertama.

Tema keempat dengan tema kapal bajak laut

\begin{tabular}{|l|l|l|l|l|l|l|l|l|}
\hline No & Nama & \multicolumn{7}{|c|}{ Jenis Gambar } \\
\cline { 4 - 9 } & Siswa & $\mathbf{1}$ & $\mathbf{2}$ & $\mathbf{3}$ & $\mathbf{4}$ & $\mathbf{5}$ & $\mathbf{6}$ & $\mathbf{7}$ \\
\hline 1 & S1 & & & & & & $\mathrm{V}$ & $\mathrm{V}$ \\
\hline 2 & S2 & $\mathrm{V}$ & & $\mathrm{V}$ & $\mathrm{V}$ & $\mathrm{V}$ & $\mathrm{V}$ & $\mathrm{V}$ \\
\hline
\end{tabular}

\begin{tabular}{|c|c|c|c|c|c|c|c|c|}
\hline 3 & S3 & 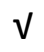 & & & V & & $v$ & $\mathrm{~V}$ \\
\hline 4 & S4 & $v$ & & & 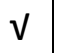 & & & $\mathrm{V}$ \\
\hline 5 & S5 & $\mathrm{V}$ & $\mathrm{V}$ & $\mathrm{V}$ & 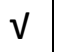 & $V$ & $\mathrm{~V}$ & $\mathrm{~V}$ \\
\hline 6 & S6 & $v$ & & $V$ & $V$ & $\mathrm{~V}$ & $\mathrm{~V}$ & $\mathrm{v}$ \\
\hline 7 & S7 & $\mathrm{V}$ & & $\mathrm{V}$ & 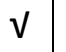 & $V$ & $v$ & $v$ \\
\hline 8 & S8 & 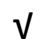 & & & & & $V$ & $v$ \\
\hline 9 & S9 & $\mathrm{V}$ & & & & & $\mathrm{V}$ & $v$ \\
\hline 10 & $\mathrm{~S} 10$ & $\mathrm{~V}$ & & V & 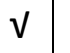 & $\mathrm{V}$ & $v$ & $v$ \\
\hline 11 & S11 & $v$ & & & V & & & \\
\hline 12 & S12 & $v$ & & $v$ & 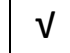 & 1 & & \\
\hline
\end{tabular}

Ket: tabel 1.gambarapel, 2.gambar meriam, 3.gambar kapten4. gambarburung hantu, 5 . gambarbajak laut, 6. gambarbendera, 7. gambarpedang.

Tema keempat dengan tema kapal bajak laut terdiri dari 7 gambar diantaranya gambar apel, meriam, kapten, burung nuri, bajak laut, tengkorak, pedang. Gambar pertama apel hanya 1 siswa yang tidak dapat menjawab yaitu kode $\mathrm{S} 1$ dan yang lain dapat menjawabnya. Apel adalah buah yang umum dan dapat dijumpai dimanapun sehingga banyak siswa yang dapat menyebutkannya. Gambar kedua yaitu meriam. Meriam atau adalah senjata berat yang larasnya besar dan panjang, terdapat peluru yang besar dan terdapat roda untuk memudahkan pengangkutannya. Gambar meriam hanya dapat dijawab oleh 1 siswa yaitu kode S5, S5 dapat menjawab semua gambar yang peneliti tunjukkan. Siswa yang lain mengatakan tidak pernah melihat gambar meriam, walau peneliti sudah menjelaskannya tetap saja siswa tidak dapat menjawab. Gambar berikutnya adalah kapten dan bajak laut dapat dijawab 
oleh kodeS2, S5, S6, S7, S10, S12.Jadi sebagian siswa dikatakan mampu menjawab gambar yang peneliti tunjukkan.

Selanjutnya ada gambar burung nuri, dari 12 siswa gambar burung nuri tidak dapat dijawab oleh 3 siswa yaitu kode S1, S8, S9. Jadi lebih banyak siswa yang dapat menjawab dikarenakan burung nuri dapat dijumpai di buku-buku sekolah. Begitu juga dengan tengkorak dari 12 siswa yang tidak dapat menjawab 3 siswa yaitu kode S4, S11, dan S12. Tengkorak juga sering ditemukan anak-anak karena tengkorak biasanya adalah mainan anak. Terakhir ada gambar pedang, pedang adalah senjata yang digunakan orang untuk berperang. Dari 12 siswa hanya satu siswa yang tidak dapat menjawab yaitu kode S11. Jadi, pemerolehan bahasa (kosakata) setiap anak berbeda hal ini dikarenakan faktor keluarga dan lingkungan.

Tema kelima dengan tema ladang pertanian

\begin{tabular}{|c|l|c|c|c|c|c|c|}
\hline \multirow{2}{*}{ No } & Nama & \multicolumn{6}{|c|}{ Jenis Gambar } \\
\hline & Siswa & $\mathbf{1}$ & $\mathbf{2}$ & $\mathbf{3}$ & $\mathbf{4}$ & $\mathbf{5}$ & $\mathbf{6}$ \\
\hline 1 & S1 & V & V & & & & \\
\hline 2 & S2 & V & V & V & & & \\
\hline 3 & S3 & V & & V & & & \\
\hline 4 & S4 & V & V & & V & & \\
\hline 5 & S5 & V & V & V & & & \\
\hline 6 & S6 & V & V & V & & V & V \\
\hline 7 & S7 & V & V & V & & & \\
\hline 8 & S8 & V & V & & & & \\
\hline 9 & S9 & V & V & V & & & \\
\hline
\end{tabular}

\begin{tabular}{|l|l|l|l|l|l|l|l|}
\hline 10 & S10 & v & v & v & & V & \\
\hline 11 & S11 & v & V & & & & \\
\hline 12 & S12 & v & v & V & & & V \\
\hline
\end{tabular}

Ket: tabel 1. gambarayam, 2. gambar sapi, 3. gambar petani, 4. gambarjerami, 5 . gambar domba, 6. gambar traktor.

Tema kelima dengan tema kapal bajak laut terdiri dari 6 gambar diantaranya ayam, sapi, petani, jerami domba, dan traktor. Gambar sapi dapat dijawab oleh semua siswa, dikarenakan ayam bisa dijumpai dimanapun. Gambar sapi, hanya 1 siswa yang tidak dapat menjawab yaitu kode S3. Berikutnya gambar petani, dari 12 siswa yang tidak dapat menjawab 4 siswa yaitu kode S1, S4, S8, dan S11. Petani adalah orang yang bekerja di sawah, dari 12 siswa lebih banyak yang dapat menjawab gambar petani.

Berikut adalah gambar jerami, jerami adalah pohon padi yang telah kering. Biasanya setelah panen, petani akan membakar jerami agar sawah dapat ditanami tanamam lagi. Jerami hanya dijawab oleh 1 siswa yaitu kode $\$ 4$, yang lain tidak dapat menjawab. Hal ini dikarenakan jerami adalah bahasa Indonesia, sedangkan masyarakat di Paud Al-Istiqlal mayoritas adalah suku Madura dan mengatakan jerami adalah dremien. Dremien adalah jerami dalam Bahasa Madura.

Terakhir adalah gambar domba dan traktor. Domba sejenis binatang seperti kambing, dan traktor adalah alat yang 
digunakan petani untuk melunakkan tanah. Dengan traktor yang tadinya tanah kering dan keras menjadi lunak dan lembut dan siap ditanami tanaman kembali. Kalau dulu sebelum ada traktor, petani menggunakan sapi untuk melunakkan tanah. Dari 12 siswa, domba dan traktor dapat dijawab oleh dua siswa saja, yaitu kode $\mathrm{S} 6$ dan $\mathrm{S} 10$ menjawab domba, sedangkan kode S6 dan S12 dapat menjawab traktor. Saat peneliti bertanya kepada siswa yang tidak dapat menjawab domba dan traktor, mereka mengatakan bahwa domba mereka katakan kambing dan traktor mereka katakan "yang di sawah itu". Jadi, dari tema pertanian, banyak siswa yang belum bisa menjawab gambar jerami, domba, dan traktor karena mereka tidak tahu apa nama benda-benda tersebut.

Tema keenam dengan tema laut

\begin{tabular}{|c|c|c|c|c|c|c|c|c|}
\hline \multirow{2}{*}{ No } & \multirow{2}{*}{$\begin{array}{l}\text { Nama } \\
\text { Siswa }\end{array}$} & \multicolumn{7}{|c|}{ Jenis Gambar } \\
\hline & & 1 & 2 & 3 & 4 & 5 & 6 & 7 \\
\hline 1 & S1 & $\sqrt{ }$ & $\sqrt{ }$ & $\sqrt{ }$ & & & & V \\
\hline 2 & $\mathrm{~S} 2$ & V & V & V & v & V & V & 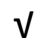 \\
\hline 3 & S3 & & V & $\mathrm{V}$ & $\mathrm{V}$ & $\mathrm{V}$ & & $\mathrm{V}$ \\
\hline 4 & S4 & & $\mathrm{V}$ & $\sqrt{ }$ & & $\sqrt{ }$ & $\sqrt{ }$ & $\checkmark$ \\
\hline 5 & S5 & v & $\mathrm{V}$ & v & & v & V & $\checkmark$ \\
\hline 6 & S6 & & V & V & V & V & V & $\sqrt{ }$ \\
\hline 7 & S7 & & V & V & $\sqrt{ }$ & V & $\sqrt{ }$ & 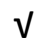 \\
\hline 8 & S8 & & $\mathrm{V}$ & v & & & & $\mathrm{V}$ \\
\hline 9 & S9 & & V & V & & V & & \\
\hline 10 & S10 & & V & v & & v & & $v$ \\
\hline 11 & S11 & & $\sqrt{ }$ & $\sqrt{ }$ & & & & \\
\hline 12 & S12 & & V & V & & V & & v \\
\hline
\end{tabular}

Ket: tael 1. gambar penyelam, 2.

gambarlkan, 3. gambar kapal nelayan, 4. gambarjala, 5. gambar tiram, 6. gambar kuda laut,

7. gambar paus.

Tema keenam dengan tema laut terdiri dari 7 gambar diantaranya penyelam, ikan, kapal nelayan, jala, tiram, kuda laut, dan paus. Gambar ikan dan kapal nelayan dapat dijawab oleh semua siswa karena gambar tersebut bersiat umum. Gambar penyelam dapat dijawab oleh kode S1, S2, $\mathrm{S} 5$ dan yang lain tidak dapat menjawab. Hal ini dikarenakan gambar penyelam terasa asing dan jarang mereka temukan. Begitupun dengan jala, hanya tiga siswa yang dapat menjawab yaitu kode S2, S3, S6 dan S7. Jala juga terasa asing dan jarang mereka temukan.

Gambar berikutnya tiram dan paus kebanyakan siswa dapat menjawab. Tiram tidak dijawab oleh kode S1, S8, dan S11, sedangkan paus tidak dapat dijawab oleh kode S9 dan S11. Tiram dan paus sering ditemukan dibuku-buku gambar anak-anak. Gambar terakhir adalah gambar kuda laut. Kuda laut adalah hewan yang hidup di laut dan bentuknya seperti kuda sehingga dinamakan kuda laut. Gambar kuda laut hanya dapat dijawab oleh kode S2, S4, S5, S6, dan S7, yang lain tidak dapat menjawab. Kuda laut adalah hewan yang tidak dapat ditemui di sekitar kita kecuali di daerah laut. Jadi, hal ini yang menyebabkan hanya beberapa anak yang dapat menjawab. 


\section{SIMPULAN}

Berdasarkan hasil penelitian di Paud Al-Istiqlal dari 6 tema, siswa dapat menjawab atau memperoleh kosakata yang sering mereka jumpai di lingkungan sekitar. Gambar-gambar yang menurut mereka asing dan mungkin pertama kali mereka temui ketika peneliti tunjukkan masih tidak dapat mereka sebutkan. Hal ini dikarenakan bahasa yang dimiliki setiap anak berbedabeda. Mereka dapat menyebutkan nama gambar dikarenakan mereka pernah tahu gambar itu sekilas entah dibuku, di jalan, atau dimanapun. Sehingga ketika peneliti jelaskan nama gambar tersebut mereka dapat menjawab dikarenakan pernah tahu gambar tersebut.Berbeda dengan anak yang tidak dapat menjawab, mereka mengatakan tidak tahu gambar tersebut dan tidak pernah melihat sebelumnya sehingga ia tidak dapat menyebutkan.

Jadi, pemerolehan bahasa setiap anak berbeda-beda, hal ini dikarenakan bedanya status sosial, keluarga, dan lingkungan. Banyaknya pertanyaan anak kepada orang tuanya adalah wujud rasa penasaran anak tentang apa nama benda disekitarnya. Jika orang tua yang sabar mendampingi anak, ia akan menjawab semua pertanyaan anak. Dengan demikian akanbanyak kosakata yang anak dapatkan. Biasanya pemerolehan bahasa yang anak dapat, tidak hanya satu atau dua kali dikenalkan, misal gambar lampu merah, jika anak sering melihat gambar lampu merah, maka lambat laun akan tahu bahwa gambar tersebut adalah lampu merah. Ketika ia menjumpainya di jalan ia akan mengatakan bahwa itu adalah lampu merah.

\section{DAFTAR RUJUKAN}

Candrasari, Liring Ayu. 2014.Pemerolehan Bahasa Anak Usia 3-4 Tahun di Desa Gembong Kecamatan BelikKabupaten Pemalang: Kajian Psikologi.(http://eprints.ums.ac.id/i d/eprint/29874). Diakses tanggal 27 Agustus 2018.

Chaer, Abdul. 2009. Psikolinguistik: Kajian Teoretik. Jakarta: Rineka Cipta.

Dardjowidjojo, Soenjono. 2005. Psikolinguistik Pengantar Pemahaman Bahasa Manusia. Jakarta: Yayasan Obor Indonesia.

Kridalaksana, Harimurti. 2008. Kamus Linguistik. Jakarta: GramediaPustaka Utama.

Mahsun. 2011. Penelitian Bahasa: Tahapan Strategi, Metode, dan Tekniknya. Jakarta:PT RajaGrafindo Persada.

Moleong, Lexy J. 2010. Metodologi Penelitian Kualitatif. Bandung: PT Remaja Rosdakarya. 
Setyosari, Punaji. 2010. Metode Penelitian dan Pembangunan. Surakarta: Kencana Prenada Media Group.

Soejito dan Saryono, Djoko. 2011. Kosakata Bahasa Indonesia. Malang:Aditya Media Publishing.

Werdiningsih, Dyah. 2011. Strategi Pembelajaran Bahasa Anak. Jakarta: Nirmana Media.

Yanti, Prima Gusti. 2016.Pemerolehan Bahasa Anak: Kajian Aspek Fonologi Pada Anak Usia 2-2,5 Tahun. Jurnal IImiah VISI PPTK PAUDNI-Vol.11, No.2, Desember 2016. journal.unj.ac.id/unj/index.php/jiv/ article/download/3660/2692/.Diaks es tanggal 28 September 2018. 